\title{
Yaygın cilt metastazları: Küçük hücreli olabilir mi?
}

Timuçin ALAR ${ }^{1}$, İsmail Ertuğrul GEDİK²

\begin{abstract}
$\overline{O ̈ z}$
üçük hücreli akciğer kanseri (KHAK) nöroendokrin bir tümör olup sıklıkla yaygın astalık olarak kendini gösterir. Hastaların çoğunda uzak metastaz vardır ve başlangıç :davisi sistemik kemoterapidir. KHAK olan hastalar tedavi almadan yaşayamazlar ve en nemli faktör hastalığın çabuk tanı almasıdır. Bu yazıda cilt nodülü eksizyonu ile tan onan yaygın hastalıklı KHAK' li bir olgu sunulmuştur.
\end{abstract}

Anahtar Kelimeler: Küçük hücreli, cilt metastazı, cerrahi, akciğer kanseri, toraks
Yayın Bilgisi

Gönderi Tarihi:13.06.2018

Kabul Tarihi:12.11.2018

Online Yayın Tarihi:31.03.2019

DOI: $10.26453 /$ otjhs.433606

Sorumlu Yazar Timuçin ALAR

\section{Widespread skin metastases: Could it be small cell?}

Timuçin ALAR ${ }^{1}$, İsmail Ertuğrul GEDİK ${ }^{2}$

\begin{abstract}
Small cell lung cancer (SCLC) is a neuroendocrine tumor usually presents with disseminated disease. The majority of patients have distant metastases and initial therapeutic management is systemic chemotherapy. SCLC patients almost never survive without treatment and most important factor is than prompt diagnosis of the disease. A case of SCLC with extensive stage disease that was accurately diagnosed via excised skin nodule is presented in this report.
\end{abstract}

Keywords: Small cell, skin metastase, surgery, lung cancer, thorax
Article Info

Received:13.06.2018

Accepted:12.11.2018

Online Published:31.03.2019

DOI: $10.26453 /$ otjhs.433606

Corresponding Author

Timuçin ALAR

\footnotetext{
${ }^{1}$ Çanakkale Onsekiz Mart University Medical Faculty Department of Thoracic Surgery

${ }^{2}$ Erzurum Regional Education and Research Hospital Department of Thoracic Surgery
}

\section{INTRODUCTION}

Cancer is an important health problem worldwide and 1.7 million new cancer case and 610.000 cancer deaths are projected to occur in the United States in 2018.1 Lung cancer (LC), is the most common type of cancer seen in human body. It has been reported that there are approximately 1.6 million new LC case and 1.4 million deaths caused by LC each year. Small cell lung cancer (SCLC) constitutes about $10-15 \%$ of the newly diagnosed LC cases. LC can metastasize to a wide variety of organs and the incidence of skin metastasis in LC is between $1-12 \% .2$ A case of SCLC, which has metastasized to many organs including skin and diagnosed with an excisional biopsy performed on one of the skin metastases.

\section{CASE}

72-year-old male patient presented to a clinics with cough, malaise and widespread pain throughout entire body. Physical examination and radiological tests revealed two masses in the right upper lobe of the lung. Patient was referred to our clinics for transthoracic fine needle aspiration biopsy (TTFNAB). His medical history revealed that he had malaise and unproductive cough for two months. Physical examination revealed a blood pressure of 128/88 $\mathrm{mm}$ 
$\mathrm{Hg}$, a fever of $36.3^{\circ} \mathrm{C}$, a heart rate of 78/min, and a diminished lung auscultation sounds on the right upper zone. He had several deeply located, fixed and rigid right supraclavicular lymphadenopathies. He also had skin nodules at bilateral arcus costara which were about $15 \times 15 \mathrm{~mm}$ in diameter, rigid and fixed to the surrounding tissues and several expansive masses in several bilateral ribs. He had a smoking history of 90 packages/year and was currently smoking 4-5 cigarettes a day. Patient's posterior-anterior chest $\mathrm{x}$-ray revealed two separate masses one in the right upper zone at $30 \times 20 \mathrm{~mm}$ in diameter with irregular borders and one in the right middle zone at $60 \times 50 \mathrm{~mm}$ in diameter and irregular borders. Positron emission tomography with computerized tomography (PET/CT) was performed. PET/CT revealed increased fluorodeoxyglucose (FDG) levels in both lesions in the right upper lobe of the lung. In addition to these, there were multiple lesions in brain, various lymph nodes (submandibular, lower cervical, all mediastinal, bilateral axillary and intraabdominal stations), liver, bilateral adrenal glands, subcutaneous lesion throughout the body, bones (left clavicle, thoracic $2^{\text {nd }}$ and $11^{\text {th }}$, lumbar $4^{\text {th }}$ and $5^{\text {th }}$ vertebrae, left humeral head, multiple ribs pelvic bones, left femoral neck and bilateral femoral trochanters) with increased FDG levels (Figure 1). According to the multiple lymph nodes and multi organs smooth limited opacity, patient is diagnosed as broad metastatic L. Excisional biopsy was performed to the skin nodule located on the left arcus costarum under local anesthesia (Figure 2). Patient was discharged on the same day as he had no additional symptoms in postoperative period and his physical examination didn't reveal any significant change. The pathological diagnosis of the mass was SCLC, thus the patient was diagnosed as stage IV LC and referred to the Oncology clinics.

\section{DISCUSSION}

SCLC, which is one of the neuroendocrine tumors of lung, can be described pathologically as a malignant tumor that includes low amount of cytoplasm, has fine granular chromatin, usually does not have a nucleolus and constitutes epithelial tumors with uncertain borders. ${ }^{3,4}$ SCLC is usually seen in men older than 70 and have a history of long term smoking. The complaints of these patients usually start 812 weeks before admission. A central large tumor with widespread mediastinal lymph node involvement is usually the findings at the time of admission. ${ }^{4}$ Our case is also compatible with this knowledge as he was older than 70 and presented with cough, 
malaise and widespread pain which started 2 months ago.

SCLC usually grows fast and metastasizes to mediastinal lymph nodes and remote organs in an early period. ${ }^{5}$ This situation causes the patients to be diagnosed at a later stage. Our case also had widespread mediastinal lymph node involvement and remote organ metastases similar to this knowledge. Metastatic skin nodules are usually seen in adenocarcinomas but they are also reported in SCLC. The presence and high number of metastatic skin nodules, the presence of remote organ metastasis and the primary tumor being SCLC are considered to be bad prognostic factors in LC. ${ }^{6}$ Our case had all these criteria.

SCLC is highly susceptible to chemotherapy. Because of this the mainstay of treatment in these patients is chemotherapy. Etoposide and platinum derived salts (carboplatin, cisplatin) are usually chosen at the initial phase. ${ }^{4}$ Radiotherapy can also be added to the treatment regime if the disease is limited. But the role of surgery is very limited because of fast spreading of the disease at an early phase. Surgery can only be performed in stage 1 or 2 disease with adjuvant chemo-radiotherapy. Many researchers report that surgery does not improve the prognosis significantly and some even report an adverse effect on the prognosis of these patients. ${ }^{5-7}$

LC is one of the deadliest cancers on earth with the 5 year overall survival rates of $15 \% .^{8}$ This ratio changes between $5-8 \%$ for SCLC. ${ }^{3}$ This can be attributed to the disease's advanced stages at the time of diagnosis. Skin metastasis on the other hand decreases the median survival in LC to 5-6 months.

If we evaluate through our case, we did exactly the only thing we should do as standard in a patient who admitted to our outpatient clinics in order to undergo a biopsy from a mass found in his lung: a proper physical examination. Work in a small or large medical center, this simple but effective method established the diagnosis without the need of more advanced techniques. Excisional biopsy can also be performed in almost every center and under every condition. But performing TTFNAB or taking CT requires advanced machines and personnel. In addition to these facts their complications are much more severe than excising a skin nodule's.

As a conclusion, prompt and accurate diagnosis is the primary procedure in LC. All physicians' primary goal is not to neglect proper physical examination especially in high-risk patients without complaining the deficiencies of the present conditions. 


\section{REFERENCES}

1. Siegel RL, Miller KD, Jemal A. Cancer statistics, 2018. CA Cancer J Clin. 2018;68(1):7-30.

2. Mollet TW, Garcia CA, Koester G. Skin metastases from lung cancer. Dermatol Online J. 2009;15(5):1.

3. Davidson MR, Gazdar AF, Clarke BE. The pivotal role of pathology in the management of lung cancer. J Thorac Dis. 2013;5(S5):S463-S478.

4. van Meerbeeck JP, Fennel DA, De Ruysscher DKM. Small-cell lung cancer. Lancet. 2011;378:1741-55.

5. Inoue M, Sawabata N, Okumura M. Surgical intervention for small-cell lung cancer: what is the surgical role? Gen Thorac Cardiovasc Surg. 2012;60:401-5.

6. Videtic GMM. The Role of Radiation Therapy in Small Cell Lung Cancer. Curr Oncol Rep. 2013;15:405-10.

7. Jones CD, Cummings IG, Shipolini AR, McCormack DJ. Does surgery improve prognosis in patients with small-cell lung carcinoma? Interact Cardiovasc Thorac Surg. 2013;16:375-80.

8. Daniels MG, Bowman RV, Yang IA, Govindan R, Fong KM. An emerging place for lung cancer genomics in 2013. J Thorac Dis. 2013;5(S5):S491-S497. 


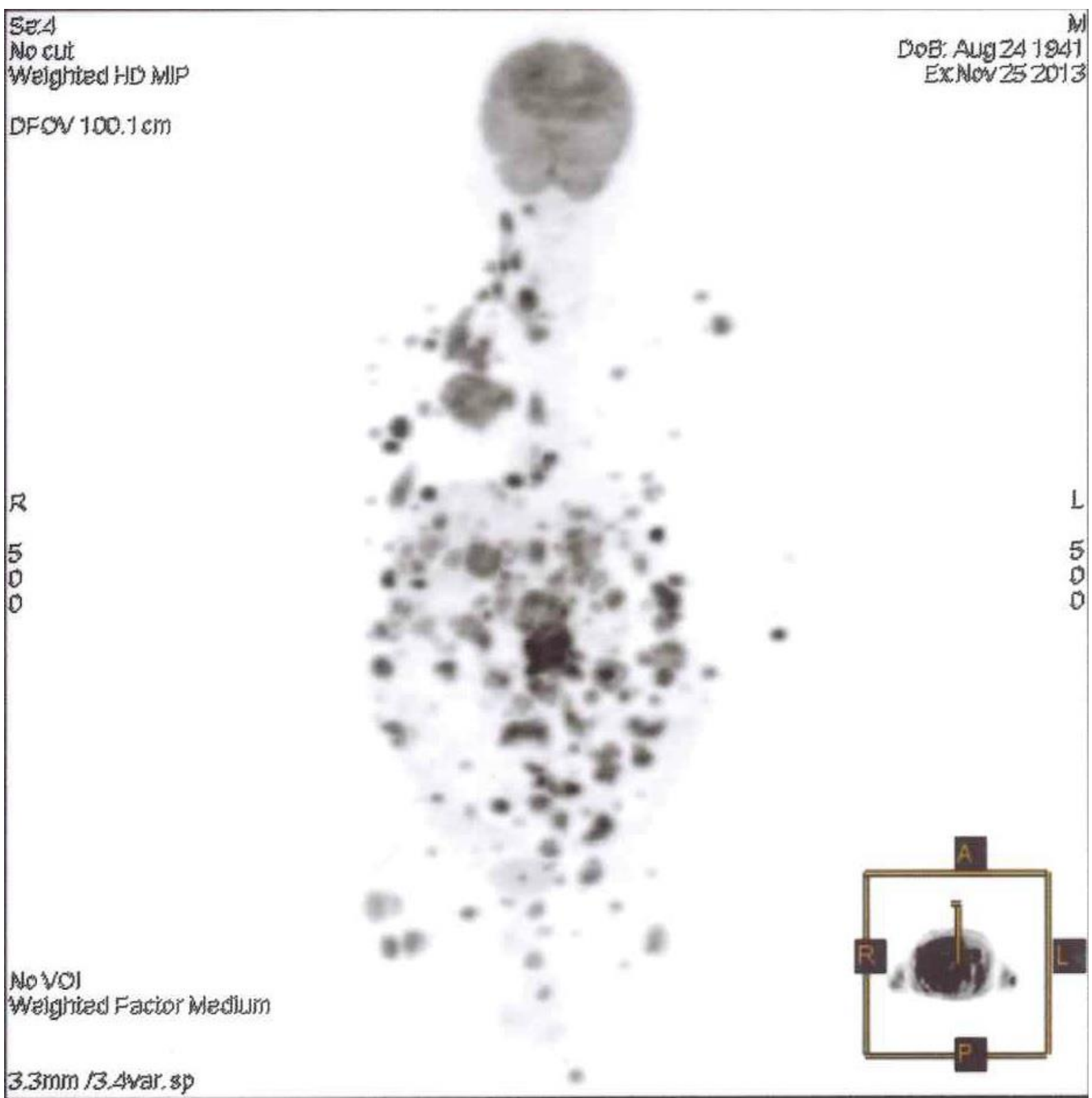

Figure 1. Widespread metastases of the patient in positron emission tomography 


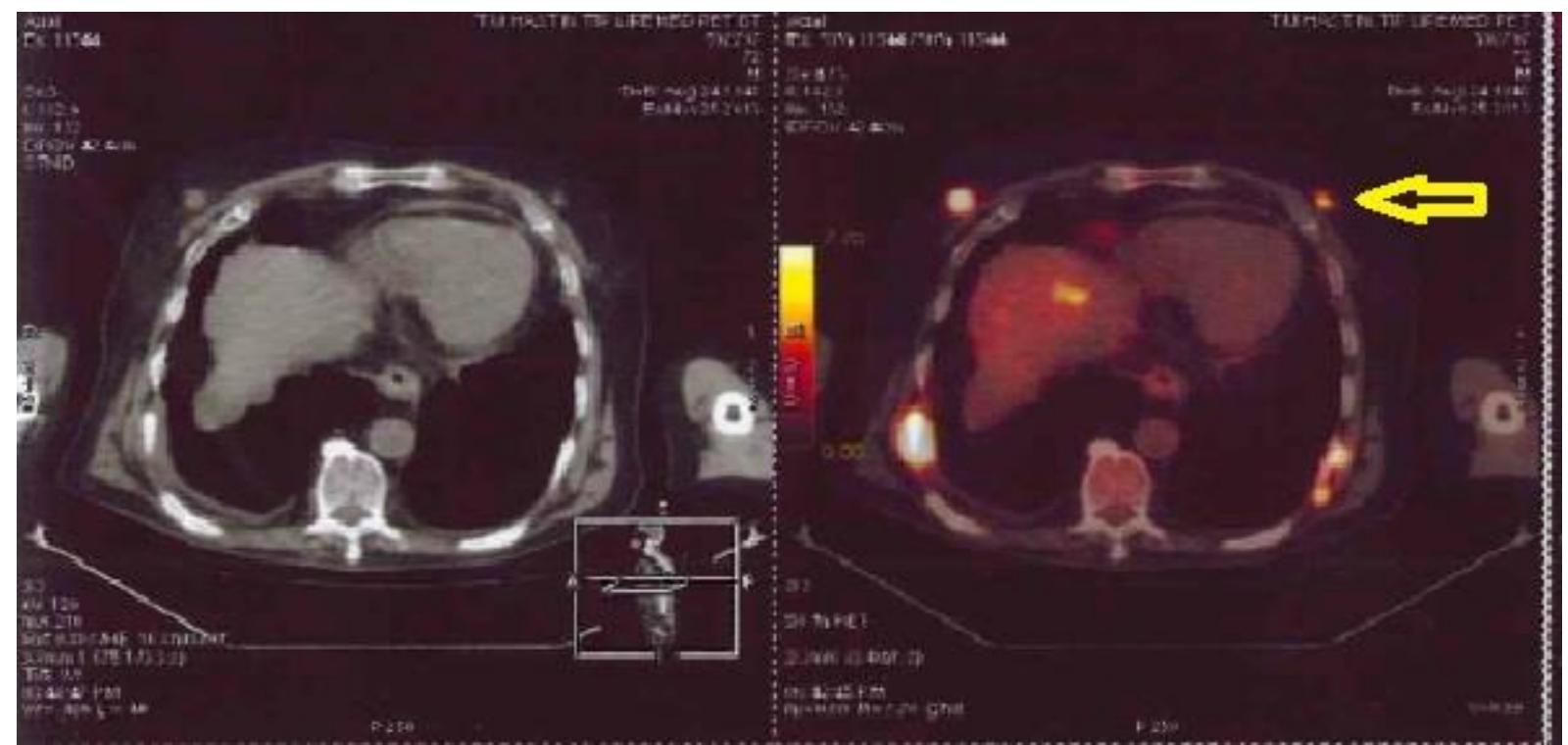

Figure 2. Excised skin nodule 